\title{
Consumer views of community pharmacy services in Bangalore city, India
}

\author{
Geetha JAYAPRAKASH, Munna L. RAJAN, Ponnushankar SHIVAM.
}

Received (first version): 22-Mar-2009

Accepted: 14-Jul-2009

\begin{abstract}
${ }^{*}$
Objective: The opinion about pharmacy services was studied using an instrument which measured satisfaction with pharmacy services. The main focus of the instrument was to assess patients' opinion and expectation of the present pharmacy services. Method: The instrument contained 20 items, which were grouped based on their similarity into eight dimensions, namely, General satisfaction, Interpersonal Skill, Evaluation, Gathering nonmedical information, Trust, Helping Patients, Explanation, and Finance. Chance random sampling was done and the participants were the general public above the age of 18 years. The main outcome measure was to study participants' opinion regarding the current and desired pharmacy services. Descriptive statistics are presented for the satisfaction dimension score. The level of satisfaction with the different dimensions was compared across the different demographic characteristics.

Result: The study results revealed significant difference in the General satisfaction and Interpersonal skill amongst the gender. Significant difference was seen in the Helping patients, Evaluation and Explanation skill among the various age groups. Education background showed significant difference in evaluation, Gathering-nonmedical information, Helping patients and Explanation skills of the pharmacist. There was an overall satisfaction dimension score of $56.83 \%$ in the current practice and $68.83 \%$ in the desired practice.

Conclusion: Awareness about pharmacy service continuing education programme for practicing pharmacist will heighten the pharmacy profession in our country.
\end{abstract}

Keywords: Community Pharmacy Services. Consumer Satisfaction. Professional Practice. India.

*Geetha JAYAPRAKASH. M.Pharm. Lecturer. R.R College of Pharmacy. Bangalore (India).

Munna L. RAJAN. M.Pharm. Lecturer. R.R College of Pharmacy. Bangalore (India).

Ponnushankar SHIVAM. M.Pharm, PhD.

Assitant.Professor. JSS College of Pharmacy, OOty (India)

\author{
VISIÓN DE LOS CONSUMIDORES DE LOS \\ SERVICIOS DE FARMACIA COMUNITARIA \\ EN BANGALORE CITY, INDIA
}

\section{RESUMEN}

Objetivo: Se estudió la opinión de los servicios de las farmacias usando un instrumento que media la satisfacción con los servicios. El principal foco del instrumento era evaluar la opinión y las expectativas de los actuales servicios de las farmacias.

Método: El instrumento contenía 20 ítems, que estaban agrupados, en función de su similitud, en 8 dimensiones, específicamente, satisfacción general, habilidades interpersonales, evaluación, recogida de información no-médica, confianza, ayuda a pacientes, explicación, y financieros. Se realizó un muestreo aleatorio y los participantes eran público general mayor de 18 años. La variable de resultado medida fue estudiar la opinión de los participantes en relación a los servicios actuales y los deseados de las farmacias. Se presenta la estadística descriptiva para la puntuación de la dimensión satisfacción. Se compara el nivel de satisfacción con las diferentes dimensiones con las diferentes variables demográficas.

Resultados: Los resultados del estudio revelaron diferencias significativas entre los géneros en la satisfacción general y las habilidades interpersonales. También se vieron diferencias significativas entre los grupos de edad para ayuda a los pacientes, evaluación y habilidades de explicación. El nivel educativo mostró diferencias significativas en evaluación, recogida de información no-médica, ayuda a pacientes, y habilidades de explicación del farmacéutico. Hubo una puntuación de la dimensión satisfacción global de 56,83\% en el ejercicio actual y de $68,83 \%$ en la práctica deseada.

Conclusión: El conocimiento del programa de formación continuada de servicios farmacéuticos para farmacéuticos en ejercicio elevará la profesión farmacéutica en el país.

Palabras clave: Servicios de farmacias comunitarias. Satisfacción del consumidor. Ejercicio profesional. India.

\section{INTRODUCTION}

Satisfaction is 'an individual's judgment about the extent to which a product or service provides a pleasurable level of consumption-related fulfillment. 
Satisfaction results from 'evaluation' of a product or service that nets some emotional reaction. A judgment is made by an individual as to how well the service was provided and this judgment results in pleasure if satisfaction occurs or displeasure if dissatisfaction occurs. ${ }^{1}$

An issue that is specific to the profession of pharmacy and to pharmacists providing pharmaceutical care is that many patients do not know what to expect from their interaction with their pharmacists, or their expectations are set so low that they are easily satisfied. Farris and colleagues argue that pharmacists should aim to provide a high level of pharmaceutical care services even if the patients do not currently expect to receive them. ${ }^{2}$

In their review of patient satisfaction literature, Aharony \& Strasser ${ }^{3}$ observed and concluded that 'while research has not yet found a simple, direct correlation between patient satisfaction and improved outcome, satisfied patients seem more likely to comply with their treatment. Given the observation that Aharony \& Strasser have made there are some important implication for the profession of pharmacy. First, from a business perspective, satisfied patients are more likely to continue using health care services and to maintain a relationship with a specific health care provider. Satisfied patients can be presumed, as repeat customers and display loyalty to a specific pharmacy. They may even be willing to recommend its services to others. Secondly, from clinical perspective, because satisfied patients comply with medical regimen (including medications) participate in their own treatment and cooperate with their health-care providers, one can conclude that, this will facilitate the provision of pharmaceutical care, their clinical outcomes will be superior owing to improved adherence, and from legal or risk management perspective, satisfied patients are less likely to complain to professional boards or societies or to seek legal action against pharmacist.

In this concept of patient satisfaction, Williams ${ }^{4}$ argue that before one measures satisfaction, one must seek to understand how patients perceive and evaluate health care services. Fortunately, in recent years, there has been considerable research studying the factors that influence the satisfaction of patients with their pharmacy experiences. The majority of this research has been done in the community pharmacy settings. There are several validated surveys, from various research works, available for pharmacists to use in their own pharmacies to assess patient satisfaction. It is strongly recommended that pharmacists use one of these surveys rather than develop their own survey, given the difficulties in designing their own survey, given the difficulties in designing a valid and reliable instrument that adequately measure satisfaction.

Patient satisfaction is a primary outcome that may be defined as the extent to which an individual's needs and wants are met. $^{5}$ Measures of patient satisfaction are increasingly being used to assess the competency of health care providers and the quality of care, particularly as satisfaction relates to continuity of care. ${ }^{6-8}$ To evaluate the changes in the consumer satisfaction from the provided pharmacy services a tetra-class model was used, which permits the manager to see if there are important changes in the consumer classification of service elements and to create measures for improving the quality of services. ${ }^{9}$ Satisfied patients have been shown to have a more positive relationship with their health care provider $^{10,11}$ and they are also more likely to continue to use their services. ${ }^{12,13}$ The literature on this topic lends support to the view that satisfaction is a function of expectation. In the pharmacy literature, studies have reported the relationship between expectations and satisfaction. ${ }^{14-16}$ Many community pharmacists probably do not realize to what extent the general public expects them to advise them on matter concerning medicines, minor illness and general health education.

This study was undertaken in order to assess the perception the public has towards the service it expects and the service it receives from community pharmacists.

\section{METHODS}

The findings and discussion presented in the paper are based on the data collected from a study on consumer perception of and attitudes to community pharmacy services. The study was conducted in North Bangalore city in India, from June to December 2006 which has a population of 21 , 43,605 (aged 18 yrs above) and the number of pharmacies in this area is around 800-1000. The survey of public attitudes towards pharmacy was carried out by using questionnaire developed from instruments used in previous studies.

Chance random sampling was done and population with age group above 18 years was included in the study. Interviewer approached people at their homes, institutions (schools \& colleges) and work place (office \& shops) with the survey form. In introducing the questionnaire to prospective respondents, it was emphasized that the survey was designed to tap actual experience of pharmacy. Although the survey has been designed for selfcompletion, the interviewer offered to complete the survey form with the participant if this was desired. The questionnaire took about 15 minutes to complete.

Patient satisfaction in the current practice and their expectations in the desired practice with the pharmacy services were assessed by using a 20item instrument based on previous work. ${ }^{17}$ (Table 1 ). The 20 items used in the questioner or survey form were framed in such a way that the respondent had to give their opinion on the current situation and what they wish for the future practice. Selected items were negatively worded to prevent the occurrence of acquiescence response set. Negatively worded items were re-coded before analysis. Individual item scoring was done by using 5-point Likert scale, with 5 indicating 'strongly agree' and 1 indication 'strongly disagree' for positively worded statements. Negative worded items were reverse scored. Items that fit together were grouped 
into dimensions. As a result eight dimensions were constructed, namely, General Satisfaction, Interpersonal Skill, Evaluation, Gathering non- medical information, Trust, Helping patients, Explanation and Finance.

\begin{tabular}{|c|c|}
\hline \multirow[t]{5}{*}{ General Satisfaction } & My pharmacy is conveniently located \\
\hline & I always go to the same pharmacy \\
\hline & I am satisfied with the pharmacy services that I receive \\
\hline & There are things about the pharmacy services I receive that could be better \\
\hline & I feel my pharmacist is more business oriented than profession oriented.* \\
\hline \multirow[t]{3}{*}{ Interpersonal Skill } & My pharmacist is always friendly \\
\hline & My pharmacist spends as much time as necessary with me. \\
\hline & If I have a question about my prescription my pharmacist is always available to help me. \\
\hline Evaluation & $\begin{array}{l}\text { My pharmacist and I discuss about the favorable effects that can be obtained from my } \\
\text { medication. }\end{array}$ \\
\hline \multirow[t]{2}{*}{$\begin{array}{l}\text { Gathering } \\
\text { information }\end{array}$} & $\begin{array}{l}\text { My pharmacist and I discuss about what needs to be done in order to get good results } \\
\text { from my medication. }\end{array}$ \\
\hline & My pharmacist and I discuss about change in my health since my last visit to him or her. \\
\hline \multirow[t]{3}{*}{ Trust } & Just talking to my pharmacist makes me feel better. \\
\hline & I am confident that my pharmacist dispenses all prescriptions correctly. \\
\hline & My pharmacist considers my feelings. \\
\hline \multirow[t]{2}{*}{ Helping patients } & My pharmacist helps me to avoid unnecessary costs related to my prescription. \\
\hline & I can talk freely about my problems with my pharmacist. \\
\hline \multirow[t]{3}{*}{ Explanation } & My pharmacist asks me question to make sure my medications are working properly. \\
\hline & My pharmacist does not tell me how to take my prescription medication. ${ }^{*}$ \\
\hline & My pharmacist never explains what my medication does. ${ }^{*}$ \\
\hline Finance & The amount my pharmacy charges me for my prescription drugs are too high. \\
\hline
\end{tabular}

Questionnaire was prepared both in English and Kannada, the local language of Bangalore. Respondents were asked to indicate their level of agreement with the items on a scale from 1 to 5 , with 1 being 'strongly agree' and 5 being 'strongly disagree, both in the current and desired practice. Descriptive statistics was reported for the respondent sample to characterize the demographic of the sample. This included Gender, Age, and Education. Descriptive statistics was also presented for the satisfaction dimension scores. Dimension score was calculated by summing the individual item scores contained in each dimensions, subtracting the minimum possible raw score, then dividing the difference by the range of possible raw scores, and then multiplying by 100 . The resulting range of possible score will be 0 to 100 , with higher score indicating a higher level of satisfaction. Then the mean percentage was presented according to the demographic details, namely, gender, age, education .Comparison of satisfaction scores between groups was made using independent group test or Analysis of Variance (ANOVA) wherever appropriate. $P$-value $<0.05$ was considered significant. The statistical analysis was done by using SPSS 10.5 version software.

\section{RESULTS}

The survey forms were distributed to 600 customers. Responses were received from 564 customers, yielding a response rate of $94 \%(n=564)$ Response from males was $65.8 \%(n=371)$ and from females it was $34.2 \%(n=193)$. In terms of age, $49.6 \%(n=280)$ of the respondents were of the age group $18-25$ years and $4.3 \%(n=24)$ were of the age group above 55 years. In terms of education background, response from graduates was maximum with $47.7 \% \quad(n=269) \quad$ (Table 2).

\begin{tabular}{|c|l|c|c|}
\hline \multicolumn{4}{|l|}{ Table 2. Demographic data of the survey } \\
\hline \multirow{4}{*}{ Gender } & & $\mathrm{N}$ & $\%$ \\
\cline { 2 - 4 } & Male & 371 & 65.8 \\
\cline { 2 - 4 } & Female & 193 & 34.2 \\
\cline { 2 - 4 } & TOTAL & 564 & 100.0 \\
\hline \multirow{4}{*}{ Education } & Primary & 37 & 6.6 \\
\cline { 2 - 4 } & Higher Secondary & 170 & 30.1 \\
\cline { 2 - 4 } & Graduate & 269 & 47.7 \\
\cline { 2 - 4 } & Post Graduate & 88 & 15.6 \\
\cline { 2 - 4 } & TOTAL & 564 & 100.0 \\
\hline \multirow{5}{*}{ Age } & $18-25$ yrs & 280 & 49.6 \\
\cline { 2 - 4 } & $26-35$ yrs & 123 & 21.8 \\
\cline { 2 - 4 } & $36-45$ yrs & 94 & 16.7 \\
\cline { 2 - 4 } & $46-55$ yrs & 43 & 7.6 \\
\cline { 2 - 4 } & $>55$ yrs & $>55$ & 4.3 \\
\cline { 2 - 4 } & TOTAL & 564 & 100.0 \\
\hline
\end{tabular}

\section{Consumer's satisfaction dimension score in the current practice}

In the current practice statistical significant difference was seen in the General Satisfaction and Interpersonal Skill dimensions among males and females, with females expressing more satisfaction with these two dimensions with a mean score of $68.01 \%$ and $62.95 \%$ respectively (Table 3 ). Statistical significant difference was seen in General Satisfaction, Evaluation, Helping Patients and Explanation dimensions among people of various age groups. People above 55 years are more satisfied with the General Satisfaction dimension with a mean score of $71.25 \%$, while people of age group 26-35 years are satisfied with the Evaluation dimension with a mean score of $59.76 \%$. Younger age group (18-25 years) feel satisfied with the Helping patients and Explanation dimension with a mean score of $57.63 \%$ and $56.85 \%$ respectively (Table 4). Education background showed significant difference in Evaluation, Gathering non-medical 
information, Helping patients and Explanation dimension. Primary educated people show more satisfaction in Evaluation and Gathering nonmedical information dimensions, with a mean score of $58.11 \%$ and $58.78 \%$ respectively, while slightly more qualified Higher Secondary qualified people express satisfaction in Helping patients and Explanation dimensions with a mean score of $58.09 \%$ and $59.17 \%$ respectively (Table 5 ). Trust and Finance dimension did not show any significant difference among various groups of people.

\section{Consumer's satisfaction dimension score in the desired practice}

Overall the dimension score of various dimensions in the desired practice was more than the current practice. However significant difference was seen in Explanation and Finance dimensions among males and females, with males desiring for more satisfaction in these dimensions with a mean score of $70.75 \%$ and $69.34 \%$ respectively (Table 3 ). No significant difference was seen in age group (Table 4), but education group showed significant difference in Interpersonal skill, Evaluation, Gathering non-medical information, Helping Patients and Explanation dimensions with Higher Secondary qualified consumers desiring for more satisfaction from these dimensions (Table 5).

\begin{tabular}{|l|c|c|c|c|c|c|}
\hline Table 3. Comparison of satisfaction dimension score in the current and desired practice (Gender Wise) \\
\hline \multirow{2}{*}{ Dimensions } & \multicolumn{3}{|c|}{ Current Practice } & \multicolumn{3}{c|}{ Desired Practice } \\
\cline { 2 - 7 } & Male & Female & P-Value & Male & Female & P-Value \\
\hline General Satisfaction & 64.38 & 68.01 & 0.003 & 70.16 & 72.38 & 0.064 \\
\hline Interpersonal Skill & 58.81 & 62.95 & 0.021 & 71.47 & 69.39 & 0.199 \\
\hline Evaluation & 50.67 & 54.40 & 0.129 & 66.91 & 65.93 & 0.668 \\
\hline Gathering non-medical information & 49.73 & 53.63 & 0.091 & 68.13 & 65.35 & 0.150 \\
\hline Trust & 59.23 & 60.15 & 0.593 & 70.40 & 71.07 & 0.669 \\
\hline Helping Patients & 54.41 & 52.78 & 0.456 & 68.83 & 65.22 & 0.067 \\
\hline Explanation & 52.88 & 54.71 & 0.374 & 70.75 & 66.84 & 0.035 \\
\hline Finance & 53.30 & 55.05 & 0.468 & 69.34 & 64.12 & 0.034 \\
\hline
\end{tabular}

\begin{tabular}{|c|c|c|c|c|c|c|c|c|c|c|c|c|}
\hline \multirow[b]{2}{*}{ Dimensions } & \multicolumn{6}{|c|}{ Current Practice } & \multicolumn{6}{|c|}{ Desired Practice } \\
\hline & $\begin{array}{c}18-25 \\
\text { yrs }\end{array}$ & $\begin{array}{c}26-35 \\
\text { yrs }\end{array}$ & $\begin{array}{c}36-45 \\
\text { yrs }\end{array}$ & $\begin{array}{c}46-55 \\
\text { yrs }\end{array}$ & $\begin{array}{l}>55 \\
\text { yrs }\end{array}$ & $p$-value & $\begin{array}{c}18-25 \\
\text { yrs }\end{array}$ & $\begin{array}{c}26-35 \\
\text { yrs }\end{array}$ & $\begin{array}{c}36-45 \\
\text { yrs }\end{array}$ & $\begin{array}{c}46-55 \\
\text { yrs }\end{array}$ & $\begin{array}{l}>55 \\
\text { yrs }\end{array}$ & $\begin{array}{c}\mathrm{p}- \\
\text { value }\end{array}$ \\
\hline General Satisfaction & 62.55 & 67.32 & 69.31 & 69.53 & 71.25 & $<0.001$ & 69.43 & 72.11 & 72.23 & 73.84 & 71.88 & 0.116 \\
\hline Interpersonal Skill & 58.72 & 62.53 & 62.15 & 57.36 & 63.54 & 0.242 & 70.24 & 69.11 & 73.67 & 73.26 & 69.44 & 0.338 \\
\hline Evaluation & 51.43 & 59.76 & 49.20 & 40.70 & 48.96 & 0.001 & 66.96 & 66.67 & 67.02 & 65.70 & 61.46 & 0.896 \\
\hline $\begin{array}{l}\text { Gathering non- } \\
\text { medical information }\end{array}$ & 52.41 & 53.66 & 47.21 & 45.35 & 47.40 & 0.158 & 68.75 & 66.16 & 66.62 & 65.70 & 58.85 & 0.238 \\
\hline Trust & 59.32 & 60.43 & 56.47 & 62.40 & 64.58 & 0.260 & 69.37 & 69.78 & 74.20 & 72.67 & 71.87 & 0.187 \\
\hline Helping Patients & 57.63 & 53.25 & 46.94 & 45.64 & 54.69 & 0.001 & 68.66 & 68.60 & 64.76 & 66.57 & 63.02 & 0.475 \\
\hline Explanation & 56.85 & 51.76 & 49.65 & 47.87 & 48.61 & 0.012 & 71.01 & 65.79 & 69.33 & 73.06 & 63.19 & 0.066 \\
\hline Finance & 51.07 & 54.07 & 56.91 & 61.05 & 61.46 & $<.001$ & 67.59 & 67.89 & 67.29 & 67.44 & 66.67 & $>.999$ \\
\hline
\end{tabular}

\begin{tabular}{|c|c|c|c|c|c|c|c|c|c|c|}
\hline \multirow{2}{*}{ Dimensions } & \multicolumn{5}{|c|}{ Current Practice } & \multicolumn{5}{|c|}{ Desired Practice } \\
\hline & $\mathrm{Pr}$ & HSC & $\mathrm{Gr}$ & $P G$ & $p$-value & $\mathrm{Pr}$ & $\mathrm{HSC}$ & $\mathrm{Gr}$ & $P G$ & p-value \\
\hline General Satisfaction & 69.46 & 63.94 & 66.17 & 65.57 & 0.122 & 73.38 & 70.35 & 70.72 & 71.59 & 0.616 \\
\hline Interpersonal Skill & 60.59 & 59.51 & 61.83 & 56.53 & 0.184 & 64.41 & 73.28 & 69.64 & 71.97 & 0.028 \\
\hline Evaluation & 58.11 & 53.09 & 53.16 & 43.47 & 0.012 & 58.11 & 69.85 & 65.15 & 68.18 & 0.047 \\
\hline $\begin{array}{l}\text { Gathering non-medical } \\
\text { information }\end{array}$ & 58.78 & 53.46 & 50.56 & 44.74 & 0.018 & 63.18 & 71.03 & 65.33 & 67.05 & 0.036 \\
\hline Trust & 59.91 & 62.25 & 58.95 & 55.97 & .083 & 67.12 & 72.35 & 69.86 & 71.12 & 0.306 \\
\hline Helping Patients & 50.00 & 58.09 & 54.69 & 44.74 & $<.001$ & 58.45 & 70.88 & 66.96 & 67.05 & 0.016 \\
\hline Explanation & 50.90 & 59.17 & 52.23 & 47.54 & 0.001 & 62.84 & 73.43 & 67.63 & 69.89 & 0.007 \\
\hline Finance & 49.32 & 51.18 & 56.32 & 53.69 & 0.178 & 64.86 & 67.94 & 67.01 & 69.60 & 0.810 \\
\hline
\end{tabular}

\section{DISCUSSION}

By analyzing the satisfaction dimension score of the various dimensions significant difference was seen in all six dimensions except Trust and Finance dimension in the current practice. Females and consumers above 55 years express more satisfaction with the General Satisfaction dimension. This may be because this group of people visit the same pharmacy and hence establish a relationship with their pharmacist than males or younger group of people, who do not show patronage of individual pharmacy. Convenience of location, good and efficient services, staff appearance, friendliness, knowledge and short waiting time for dispensing will help in developing more General satisfaction in community pharmacy services.

Females are more satisfied with Interpersonal skill than professionals and postgraduates. Communication and client satisfaction must form important elements of pharmacy practice. Awareness about pharmacy services will help consumers and pharmacist to develop good Interpersonal skill.

Consumers in general are not satisfied with the evaluation skill and gathering non-medical information of the pharmacist in the current practice. 
This can be due to lack of knowledge or communication skill of the pharmacist, which can be improved by making attendance to continuing education program a mandatory for the renewal of license.

Trust dimension was found satisfactory by all groups of people. People visit pharmacies keeping a great trust on the pharmacist.

Students, graduates and people of age group 18-25 years are of the opinion that the Explanation dimension is good, whereas Postgraduates are of the opinion that the skill is not so good. This analysis shows that Explanation is a skill which the pharmacist should be spontaneous with, while dispensing. The survey indicates that unless and otherwise asked by the customers, pharmacist do not deliver explanations on their own. Awareness should be created among the public to demand for an explanation about the drugs dispensed. People in general are unaware about the prices charged for their prescription.

The study has got its own limitations, in that the opinions expressed may not be generalized for large population of Bangalore, as the study was conducted with a cross-section of people in Northern Bangalore.

\section{CONCLUSIONS}

From the outcome of the study, conclusion can be viewed from two angles. One, from public point of view and another from pharmacists point of view. Awareness should be created amongst the public about the role of pharmacist, so that they will know what to expect from pharmacy services. Many practicing pharmacist are not aware about their professional responsibilities. The basic reasons for this situation are, level of formal professional education, individual's interest towards the practice, influence of regulatory authorities and professional bodies' motivation of practicing pharmacist towards profession. From the past one decade, Community pharmacy practice has undergone many changes in India. In order to improve the knowledge base of the practicing pharmacists, continuing education program will help. A suitable fee for providing pharmaceutical care services will motivate the pharmacists. Pharmacy in India should soon come in grip with the question of professionalism. Educators and professional bodies in India should take the lead and restructure the syllabus of the various courses to meet the ever changing needs of pharmacy.

\section{ACKNOWLEDGMENT}

The authors express their gratitude to JSS Mahavidyapeetha, Mysore, Karnataka for providing facilities for the conduct of the research work.

\section{CONFLICT OF INTEREST}

None declared.

\section{References}

1. Schommer JC 2003. Patient satisfaction. Pharmacoeconomics and Outcomes : Applications for patient care, 2nd Ed. American College of Clinical Pharmacy, Kansas city, MO:2003;316-30

2. Farris KB, Stenton SB, Samnani M, Samycia D. How satisfied are your patients? Can Pharm J. 2000;133(8):32-36

3. Aharony L, Strasser S. Patient satisfaction: What we know about and what we will need to explore. Med Care Rev. 1993;50(1): 49-79

4. William B. Patient Satisfaction: A Valid Concept? Soc Sci Med. 1994;38(4): 509-516.

5. Rossiter L, Langwell K, Wan T, Rvnyak M. Patient satisfaction among elderly enrollees and disenrollees in Medicare health maintenance organizations. Results from the National Medicare Competition Evaluation. JAMA.1989;262:57-63

6. Schommer J, Kucukarsalan S. Measuring patient satisfaction with pharmaceutical services. Am J Health Syst Pharm. 1997;54:2721-2732.

7. Dearmin J, Brenner J, Miglini R. Reportig on QI efforts for internal and external customers. J Quality Improv. 1995;21: 277-288

8. Hargie O, Morrow N, Woodman C. Consumer perceptions of and attitudes to community pharmacy services. Pharm J 1992; 249:688-691.

9. Clerfeuille F, Poubanne Y, Vakrilova M, Petrova G. Evaluation of the consumer's satisfaction using the tetra-class model. Res Social Adm Pharm. 2008; 4(3):258-271

10. Marquis M, Daves A, Ware J. Patient satisfaction and change in medical care provider: a longitudinal study. Med Care. 1983;21:821-829

11. Crosby L, Evans K, Cowles D. Relationship quality in services selling: an interpersonal influence perspective. J Marketing. 1990;54:68-81

12. Ware JE Jr, Wright WR, Snyder MK, Chu GC. Consumer perceptions of health care services: implications for academic medicine. J Med Educ. 1975;50:839-848

13. Ross C, Frommelt AG, Hazelwood L. The role of expectations in patient satisfaction with medical care. J Health Care Market. 1987;7:16-26

14. Mackowiak JI, Manasse HR Jr. Expectation for ambulatory services in traditional and office practice pharmacist. Am J Hosp Pharm. 1984;41:1140-1146.

15. David R. Mottram, James L. Ford, Brenna Markey, Kay Mitchelson. Public perceptions of community pharmacy. Pharm J. 1989;243: R 14-17.

16. Barwani S, Panton R, Morley A. Survey of public opinion about the community pharmacist as a source of health advice. Pharm J. 1987;239:R15. 
Jayaprakash G, Rajan ML.Shivam P. Consumer views of community pharmacy services in Bangalore city, India. Pharmacy Practice (Internet) 2009 Jul-Sep;7(3):157-162.

17. Volume $\mathrm{Cl}$, Farris KB, Kassam R, Cox CE, Cave A. Pharmaceutical care research and education project: patient outcomes. J Am Pharm Assoc. 2001;41(3):411-420 